Counsellia: Jurnal Bimbingan dan Konseling

Volume 11 (1) 31 - 42 Mei 2021

ISSN: 2088-3072 (Print) / 2477-5886 (Online)

DOI: $10.25273 /$ counsellia.v11i18591

Available online at: http://e-journal.unipma.ac.id/index.php/JBK

\title{
Pengembangan Aplikasi "Kawan SMK” untuk Meningkatkan Perencanaan Studi Lanjut pada Siswa SMK
}

\author{
Elwas Berdha Krismona ${ }^{1}$ 凶, Ribut Purwaningrum ${ }^{2}$, Naharus Surur ${ }^{3}$. \\ ${ }^{1}$ Fakultas Keguruan dan Ilmu Pendidikan, Universitas Sebelas Maret, Surakarta \\ email: 凶 elwasberdha@hotmail.com \\ ${ }^{2}$ Fakultas Keguruan dan Ilmu Pendidikan, Universitas Sebelas Maret, Surakarta \\ email: naning purwaningrum@staff.uns.ac.id \\ ${ }^{3}$ Fakultas Keguruan dan Ilmu Pendidikan, Universitas Sebelas Maret, Surakarta \\ Email: naharus67@staff.uns.ac.id
}

\begin{abstract}
Abstrak: Tingginya minat siswa SMK untuk melanjutkan pendidikan ke jenjang yang lebih tinggi terkendala dengan kurangnya informasi studi lanjut, kecemasan biaya pendidikan serta kecemasan akan persaingan seleksi masuk perguruan tinggi, sehingga para siswa SMK membutuhkan layanan perencaan individual guna meningkatkan perencanaan studi lanjut. Penelitian dan pengembangan ini bertujuan untuk menghasilkan prototipe 2 aplikasi "Kawan SMK" untuk meningkatkan perencanaan studi lanjut siswa SMK di Kota Surakarta. Penelitian menggunakan desain penelitian dan pengembangan Borg dan Gall (1983) yang dilaksanakan hingga tahap main product revision atau revisi produk yang dilakukan setelah uji validitas ahli menggunakan inter-rater agreement pada dua ahli bimbingan dan konseling dan dua ahli media. Hasil uji validitas ahli produk aplikasi "Kawan SMK" yang dilakukan pada dua ahli bimbingan dan konseling menunjukkan bahwa produk memiliki validitas tinggi $(0,89$ dan 0,95), sehingga pengembangan prototipe aplikasi "Kawan SMK" layak digunakan sebagai media layanan bimbingan dan konseling.

Abstract: The high interest of vocational school student to continue their education to a higher level is constrained by the lack of furthur study information, anxiety about the cost of education and anxiety about competition for college entrance selection, vocational school students need individual planning services to improve further study planning. This research intended to create a second prototype of "Kawan SMK" application to increase the higher education planning of vocational high school students in Surakarta. This research used the research and development design of Borg and Gall (1983) that was held up to main product revision phase that was held after the expert validity test used inter-rater agreement with two guidance counselling experts and two media experts. The result of the expert validity test of "Kawan SMK" application that was held with two guidance counselling experts showed that the product has a high validity $(0,89$ and 0,95$)$, so the development of the prototype of "Kawan SMK" application was proper to use as a guidance counselling service media.
\end{abstract}

Keywords: Kawan SMK, Planning for Higher Studies.

Received ; Accepted ; Published 
Citation: Krismona, E. B. Purwaningrum, R. Surur, N. (2021). Pengembangan Aplikasi "Kawan SMK" untuk Meningkatkan Perencanaan Studi Lanjut pada Siswa SMK. Counsellia: Jurnal Bimbingan dan Konseling, 11(1), 31 - 42. Doi.org/10.25273/counsellia.v11i18591

\section{$($ (c) $)$ BY-NC-SA}

Copyright @2021 Counsellia: Bimbingan dan Konseling

Published by Universitas PGRI Madiun. This work is licensed under the Creative Commons Attribution-NonCommercialShareAlike 4.0 International License

\section{PENDAHULUAN}

Menurut Evans (Damarjati, 2016) pendidikan kejuruan merupakan salah satu sistem dalam pendidikan yang mempersiapkan siswanya agar mampu bekerja pada suatu bidang. Sejalan dengan itu, Undang-undang Nomor 20 tahun 2003 Pasal 15 menjelaskan bahwa pendidikan kejuruan adalah tingkat pendidikan menengah yang mempersiapkan siswanya untuk bekerja pada bidang tertentu. Dijelaskan pula pada Peraturan Pemerintah Nomor 17 Tahun 2010 (Usman dan Darmono, 2016) mengenai Sekolah Menengah Kejuruan (SMK) merupakan salah satu pendidikan formal pada jenjang pendidikan menengah yang diselenggarakan oleh pendidikan kejuruan sebagai lanjutan dari Sekolah Menengah Pertama atau Madrasah Tsanawiyah.

Hal lain mengenai pendidikan kejuruan diungkapkan oleh Sumual dan Sumual (2016) yang mengatakan bahwa, "Vocational education is education that prepare learners for work in addition to be able to continue their education to higher level," Maksud dari pendapat tersebut adalah bahwa pendidikan kejuruan merupakan pendidikan yang menyiapkan siswa-siswanya untuk bekerja dan untuk dapat melanjutkan pendidikan ke jenjang pendidikan yang lebih tinggi. Pendidikan kejuruan juga dapat diartikan sebagai tingkatan pendidikan yang memiliki peran yang sama seperti Sekolah Menengah Atas (SMA) untuk membantu siswa mempersiapkan pendidikan lanjutan sesuai dengan penjurusan dan spesialisasi yang lebih spesifik sejak dini (Setiawan, 2017). Berdasarkan pengertian-pengertian tersebut, dapat disimpulkan bahwa pendidikan kejuruan merupakan jenjang pendidikan menengah yang mempersiapkan siswanya untuk bekerja dan melanjutkan pendidikan ke jenjang yang lebih tinggi sesuai dengan penjurusan yang dilakukan sejak dini.

CNBC Indonesia (2019) menyatakan bahwa lulusan SMK yang diharapkan dapat langsung bekerja malah menjadi penyumbang angka pengangguran terbesar di Indonesia, yaitu sejumlah 8,63\%. Selain itu Direktur Eksekutif Asosiasi Pengusaha Indonesia (Apindo), Agung Pambudi mengatakan bahwa adanya ketidaksesuaian antara kurikulum dengan perkembangan industri yang semakin pesat, serta standar perindustrian yang belum terpenuhi oleh kualitas lulusan SMK hingga mengakibatkan para lulusan SMK ini menjadi pekerja pada tingkat dasar bukan pada tenaga ahli spesialis (Setiawan, 2017). Di sisi lain lulusan SMK yang telah masuk pada jurusan tertentu sejak kelas X merupakan potensi emas untuk membantu pembangunan diberbagai bidang yang membutuhkan tenaga terdidik dan terlatih, sehingga para siswa lulusan SMK diharapkan dapat menuntaskan penjurusan mereka ke jenjang pendidikan yang lebih tinggi (Setiawan, 2017).

Dikutip dari artikel berjudul Lulusan SMK: Bekerja, Wirausaha, atau Kuliah? (Anonim, 2019), Muhadjir Effendy selaku Menteri Pendidikan dan Kebudayaan mengatakan bahwa alternatif lain bagi siswa SMK selain siap bekerja adalah siap untuk menjadi penyedia lapangan pekerjaan sehingga siswa lulusan SMK diharapkan dapat bersaing di dunia industri. Akan tetapi berdasarkan fakta di lapangan, siswa SMK masih memiliki minat wirausaha yang tergolong rendah. Hal ini dibuktikan pada hasil program peningkatan keterampilan dan kemampuan berwirausaha bagi siswa SMA/ SMK yang 
dilakukan oleh Prestasi Junior Indonesia yang bertujuan untuk menjaring usaha yang dikembangkan oleh siswa, dari program tersebut terpilih sepuluh finalis sekolah dari seluruh Indonesia dan jumlah SMK yang lolos hanya sejumlah tiga SMK (Kompas, 2019).

Penelitian-penelitian terbaru justru menggambarkan bahwa siswa SMK banyak yang memilih untuk melanjutkan pendidikan. Hal ini didukung oleh penelitian Alfurqon (2012) yang menyatakan bahwa siswa kelas XII Jurusan Teknik Kendaraan Ringan di SMK Negeri 2 Surakarta memiliki kesadaran akan pendidikan lanjut yang dipengaruhi oleh lingkungan sekitar serta keinginan akan keberhasilan akademik. Selain itu penelitian Suhirno (2011) juga menyatakan bahwa 57,6\% siswa kelas XII Jurusan Teknik Ototronik di SMK Negeri 1 Seyegen memiliki minat yang tinggi untuk melanjutkan pendidikan lanjutan, $14,11 \%$ siswa memiliki minat yang sangat tinggi untuk melanjutkan pendidikan lanjutan, 25,88\% siswa memiliki minat yang sedang untuk melanjutkan pendidikan, dan hanya $2,35 \%$ siswa yang memiliki minat yang rendah untuk melanjutkan pendidikan. Penelitian yang dilakukan pada siswa SMK Negeri se Kota Semarang menunjukkan bahwa 48\% siswa SMK Negeri di Kota Semarang memiliki minat yang tinggi untuk melanjutkan pendidikan serta $47 \%$ lainnya memiliki minat yang sangat tinggi untuk melanjutkan pendidikan tinggi (Setiaji \& Rachmawati, 2017). Sejalan dengan hal tersebut data penerimaan mahasiswa baru Universitas Sebelas Maret menunjukkan bahwa sebanyak 6,76\% dari total 8639 mahasiswa baru angkatan 2019 berasal dari SMK (Data lembaga Seleksi Penerimaan Mahasiswa Baru Universitas Sebelas Maret). Selain itu, berdasarkan hasil studi pendahuluan yang dilakukan oleh mahasiswa BK Universitas Sebelas Maret (UNS) angkatan 2012 di SMK se-Eks Karesidenan Surakarta, menyatakan bahwa 50,58\% siswa SMK sangat membutuhkan peningkatan perencanaan studi lanjut; 41,72\% siswa SMK membutuhkan peningkatan perencanaan studi lanjut; 6, 67\% kurang membutuhkan; dan $0,78 \%$ tidak membutuhkan. Berdasarkan penelitian tersebut dapat disimpulkan bahwa para siswa SMK memiliki minat yang tinggi untuk melanjutkan pendidikan ke jenjang yang lebih tinggi (Irawan, 2018: 2).

Minat siswa SMK yang tinggi untuk melanjutkan pendidikan ke jenjang lanjutan sejalan dengan kendala yang dialami para siswa SMK. Siswa SMK yang dipersiapkan untuk langsung bekerja menjadi kurang mendapatkan informasi mengenai pendidikan lanjutan. Alfurqon (2012: 70) mengemukakan bahwa salah satu kendala siswa SMK dalam merencanakan studi lanjut adalah kurangnya sosialisasi mengenai perguruan tinggi baik dari alumni yang melanjutkan studi lanjut maupun dari guru bimbingan dan konseling. Informasi mengenai pendidikan lanjut bagi siswa SMK diberikan oleh kampus-kampus swasta yang melakukan promosi di sekolah-sekolah seperti yang terdapat di SMK Negeri 1 Surakarta.

Hal ini diungkapkan oleh Drs. Daroji, guru BK SMK Negeri 1 Surakarta bahwa informasi studi lanjut biasanya dilakukan oleh kampus-kampus swasta yang melakukan promosi dan guru BK sebatas membantu dalam pendaftaran Seleksi Nasional Masuk Perguruan Tinggi Negeri (SNMPTN). Hal lain diunggapkan oleh Dra. Darwati, guru BK SMK PGRI Surakarta yang mengemukakan bahwa studi lanjut dianggap penting bagi siswa SMK karena pendidikan lanjutan dapat menunjang jenjang karier yang lebih tinggi bagi para siswa. Akan tetapi mayoritas siswa yang berasal dari golongan menengah kebawah memiliki kendala dalam hal biaya untuk melanjutkan pendidikan ke jenjang berikutnya. Penuturan Dra. Darwati diperkuat dengan penelitian yang dilakukan oleh Indriyanti, Siswandari, dan Ivada (2013) pada siswa kelas XII Akuntansi SMK Negeri 6 Surakarta yang menyatakan bahwa kendala siswa dalam melanjutkan pendidikan ke jenjang lanjutan adalah keadaan ekonomi keluarga serta persaingan dengan siswa SMA 
yang memiliki struktur kurikulum yang berbeda dengan siswa SMK. Berdasarkan Permendikbud Nomor 70 Tahun 2013 struktur kurikulum SMA mengharuskan siswa menempuh 42-44 jam pelajaran setiap minggu yang meliputi pelajaran wajib seperti Pendidikan Agama, Bahasa Indonesia, Pendidikan Pancasila dan Kewarganegaraan dan pelajaran peminatan berdasarkan rumpun ilmu Matematika dan Ilmu Pengetahuan Alam, Ilmu-ilmu Sosial maupun Bahasa. Sedangkan struktur kurikulum SMK mengharuskan siswanya menempuh 48 jam pelajaran setiap minggu yang meliputi pelajaran wajib yang sama seperti siswa SMA dan lebih menekankan mata pelajaran vokasi yang sesuai dengan program keahlian siswa.

Bersama dengan hal tersebut, Indonesia akan segera menyambut hadirnya society 5.0 yang digagas oleh Pemerintah Jepang sejak bulan Januari 2016. Onday (2019: 2) mengatakan bahwa era society 5.0 merupakan era yang menggabungkan antara teknologi, sains, dan inovasi yang tetap berbasis pada masyarakat. Era society 5.0 akan menjadikan manusia sebagai pusat tatanan masyarakat yang berbasis teknologi (Budiman, 2019). Adanya society 5.0 menyebabkan segala data dan informasi dapat dikumpulkan dan diakses melalui internet pada segala bidang kehidupan, termasuk pada bidang pendidikan (Budiman, 2019). Namun, data yang diperoleh dari Asosiasi Penyelenggara Jasa Internet Indonesia (APJII) pada tahun 2020 menyatakan bahwa sebanyak 51,5\% individu menggunakan internet untuk membuka media sosial, 32,9\% untuk komunikasi lewat pesan, 5,2\% untuk permainan, 2,9\% untuk akses layanan publik, 1,4\% untuk layanan informasi berita, dan hanya 1,3\% digunakan untuk layanan informasi berkaitan dengan pendidikan. Hal ini disebabkan karena masih minimnya pengembangan media pembelajaran berbasis web di Indonesia (Lukitaningrum, 2016: 2). Dra. Darwati, guru BK SMK PGRI Surakarta juga menerangkan bahwa di Surakarta masih belum ada web maupun aplikasi yang berisi mengenai perencanaan studi lanjut bagi siswa. Ditambahkan pula oleh Drs. Daroji selaku guru BK SMK Negeri 1 Surakarta, web-web berisi informasi bagi siswa SMK baru sebatas informasi mengenai pekerjaan atau lowongan pekerjaan. Padahal seorang guru diharapkan mampu untuk terus menerus melakukan pembaharuan berkaitan dengan pengembangan media pembelajaran berbasis web akan proses pemberian layanan tidak terbatas oleh ruang dan waktu. Tak terkecuali seorang guru BK yang dituntut agar terus melakukan pembaharuan dalam pemberian layanan BK kepada para siswanya.

Mencegah munculnya masalah yang berkaitan dengan kurangnya informasi studi lanjut, kecemasan akan biaya pendidikan serta kecemasan akan persaingan seleksi masuk perguruan tinggi, maka diperlukan layanan perencanaan individual, layanan perencanaan individual dapat dilakukan dengan berbagai strategi layanan seperti, konseling kelompok, konseling individual, konsultasi, alih tangan maupun pengembangan media (Gysbers \& Henderson, 1976 dan Depdiknas, 2008). Perencanaan individual dalam penelitian dan pengembangan ini dilakukan dengan mengembangkan media yang dapat digunakan siswa SMK untuk meningkatkan perencanaan studi lanjut melalui media web. Web merupakan situs yang berisi mengenai informasi data teks, data animasi, data gambar, data video, suara maupun gabungan dari beberapa data baik yang sifatnya dinamis maupun statis (Riyadi, Retnandi, dan Supriatna: 2013).

\section{METODE PENELITIAN \\ Rancangan Penelitian}

Penelitian ini menggunakan metode penelitian dan pengembangan, yakni penelitian yang bertujuan untuk mengembangkan atau memvalidasi produk pendidikan. Desain penelitian dan pengembangan yang digunakan pada penelitian ini mengacu pada desain penelitian dan pengembangan yang dikembangkan oleh Borg dan Gall (1983). 
Adapun prosedur yang dilakukan meliputi (1) research and information collecting, berupa melakukan tinjauan pustaka mengenai perencanaan studi lanjut, tinjauan pustaka mengenai aplikasi webview, serta pengumpulan data mengenai latar belakang penelitian yang melibatkan guru BK, orangtua, dan siswa; (2) planning, tahapan ini dilakukan peneliti dengan merumuskan rencana produk yang akan dikembangkan yakni webview "Kawan SMK" dengan melalikan konsiltasi dengan ahli; (3) develop preliminary from of product, tahapan ini dilakukan peneliti dengan mengembangkan produk yang meliputi, kumpulan materi, lembar kerja siswa, bentuk dasar aplikasi, dan buku panduan penggunaan; (4) preliminary field testing, pada tahapan ini peneliti melakukan uji validitas ahli dengan dua orang ahli di bidang bimbingan dan konseling, seorang ahli di bidang desain komunikasi visual, dan seorang ahli di bidang pendidikan teknik kejuruan.

\section{Sumber Data}

Pada penelitian dan pengembangan ini, data yang digunakan sebagai latar belakang dan tinjauan pustaka penelitian berasal dari penelitian mengenai pendidikan lanjutan bagi siswa SMK yang dilakukan oleh Suhirno (2011); Alfurqon (2012); Indriyanti, Siswandari \& Ivada (2013; Setiaji \& Rachmawati (2017). Selain itu data sumber data yang digunakan berdasarkan data studi pendahuluan yang dilakukan oleh mahasiswa BK UNS angkatan 2012, wawancara kepada guru BK di SMK Negeri 1 Surakarta, dan wawancara kepada guru BK di SMK PGRI Surakarta.

\section{Teknik Pengumpulan Data}

Teknik pengumpulan data dilakukan oleh peneliti dengan menggunakan dua cara, yakni (1) data pada tahapan research and information collecting yang diperoleh melalui hasil analisis asesmen kebutuhan yang disebar oleh mahasiswa BK UNS angkatan 2012, dan pedoman wawancara yang dibuat oleh peneliti serta (2) data pada tahapan preliminary field testing yang diperoleh melalui angket yang diberikan peneliti kepada validator ahli untuk penguji validitas produk yang dikembangkan.

\section{Teknik Analisis Data}

Teknik analisis data yang digunakan oleh peneliti berupa data kualitatif dan data kuantitatif. Data kualitatif digunakan untuk memaparkan kritik dansaran dari ahli dalam proses uji validitas ahli, sedangkan data kuantitatif digunakan untuk menghitung hasil angket uji validitas ahli dengan bantuan tabel kontingensi untuk menghitung Indeks Gregory.

Tabel 1 Kontingensi untuk Menghitung Indeks Gregory

\begin{tabular}{clcc}
\hline \multirow{2}{*}{ Keterangan } & \multicolumn{2}{c}{ Rater 1 } \\
\cline { 3 - 4 } & $\begin{array}{l}\text { Relevansi } \\
\text { Lemah }\end{array}$ & $\begin{array}{c}\text { Relevansi } \\
\text { Kuat }\end{array}$ \\
\hline \multirow{2}{*}{ Rater 2 } & \begin{tabular}{l} 
Lemah \\
\cline { 2 - 4 }
\end{tabular} & A & B \\
Kelevansi & C & D \\
\hline
\end{tabular}


Berdasarkan tabel tersebut dapat ditentukan rumus sebagai berikut:

$$
\text { Indeks Uji Ahli }=\frac{\mathrm{D}}{\mathrm{A}+\mathrm{B}+\mathrm{C}+\mathrm{D}}
$$

A mewakili relevansi lemah dari ahli 1 dan 2, B mewakili relevansi kuat dari ahli 1 dan relevansi lemah dari ahli 2, C mewakili relevansi lemah dari ahli 1 dan relevansi kuat dari ahli 2, sedangkan D mewakili relevansi kuat dari ahli 1 dan ahli 2. Apabila indeks uji ahli tersebut menghasilkan $<0,4$ maka validitas dikatakan rendah, apabila indeks uji ahli menunjukkan 0,4-0,8 maka validitas ahli dikatakan sedang, dan apabila indeks uji ahli menunjukkan $>0,8$ maka validitas ahli dikatakan tinggi.

\section{HASIL DAN PEMBAHASAN Hasil}

Penelitian dan pengembangan menggunakan hasil studi pendahuluan yang dilakukan oleh mahasiswa BK UNS angkatan 2012 di SMK yang tersebar di Karanganyar, Sragen, Boyolali, Wonogiri, Klaten, Sukoharjo, dan Surakarta yang menyatakan sebanyak 50,58\% siswa SMK sangat membutuhkan peningkatan perencanaan studi lanjut, $41,72 \%$ siswa SMK membutuhkan peningkatan perencanaan studi lanjut, 6,67\% siswa SMK kurang membutuhkan peningkatan perencanaan studi lanjut, 0,78\% siswa SMK tidak membutuhkan peningkatan perencanaan studi lanjut. Hasil studi pendahuluan tersebut diperkuat dengan wawancara yang dilakukan kepada Drs Daroji selaku guru BK SMK Negeri 1 Surakarta dan Dra. Darwati selaku guru BK SMK PGRI Surakarta yang mengatakan bahwa studi lanjut dianggap penting bagi siswa SMK agar dapat menunjang karier siswa di masa depan.

Pengembangan aplikasi "Kawan SMK" berdasarkan dari hasil kajian empirik dan kajian teoretis. Aplikasi dinamakan "Kawan SMK", yang berarti teman bagi siswa SMK dalam merencanakan pendidikan lanjutan. Aplikasi ini berisi beberapa informasi berkaitan dengan perencanaan studi lanjut, yakni informasi pengetahuan diri, informasi studi lanjut, informasi jurusan, informasi beasiswa, serta cerita alumni SMK yang melanjutkan pendidikan. Aplikasi "Kawan SMK" dapat diperoleh melalui link bit.ly/KawanSMKapk atau dapat langsung mengunjungi lama https://kawansmk.net. Produk pengembangan aplikasi "Kawan SMK" memiliki spesifikasi berupa (1) kumpulan materi yang berisi tentang materi-materi yang berkaitan dengan perencanaan studi lanjut; (2) lembar kerja siswa yang berupa soal uraian yang dapat diakses dan dikerjakan siswa melalui tautan formulir daring; (3) web yang berisi mengenai informasi pengetahuan diri, informasi studi lanjut, informasi jurusan, informasi beasiswa, dan cerita alumni SMK yang melanjutkan pendidikan; (4) aplikasi yang berfungsi menampilkan tampilan web mengenai informasi perencanaan studi lanjut bagi siswa SMK; dan (5) buku pandungan yang disusun untuk membantu guru dan siswa dalam menggunakan produk aplikasi "Kawan SMK".

Hasil uji validitas ahli prototipe 1 pengembangan aplikasi "Kawan SMK" menghasilkan prototipe 2 pengembangan aplikasi "Kawan SMK" yang telah diuji oleh dua orang ahli dibidang BK, ahli dibidang desain komunikasi visual untuk ahli media, dan ahli dibidang pendidikan teknik kejuruan untuk ahli media. Penilaian pada ahli BK berisi tiga aspek yang diadaptasi dari Badan Standar Nasional Pendidikan yang meliputi isi, penyajian produk, dan kebahasaan. Sedangkan untuk penilaian dibidang media berisi 
empat aspek yang diadaptasi dari elemen user experience yang meliputi adoptability, usability, value, dan desirability.

Dari pengkategorian hasil penilaian tersebut, selanjutnya kategori tersebut dimasukkan ke dalam tabel indeks gregory dengan dua ahli sebagai berikut:

Tabel 1 Kontingensi Kategori Indeks Gregory pada 2 Ahli BK

\begin{tabular}{cccc}
\hline & & \multicolumn{2}{c}{ Ahli 1 } \\
\hline & & Lemah & Kuat \\
\hline \multirow{2}{*}{ Ahli 2 } & Lemah & 0 & 2 \\
\cline { 2 - 4 } & & & \\
& Kuat & 0 & 17 \\
\hline
\end{tabular}

Tabel 2 Tabel Kontingensi Kategori Indeks Gregory pada 2 Ahli Media

\begin{tabular}{|c|c|c|c|}
\hline & & \multicolumn{2}{|c|}{ Ahli 1} \\
\hline & & Lemah & Kuat \\
\hline \multirow{2}{*}{ Ahli 2} & Lemah & 0 & 1 \\
\hline & Kuat & 0 & 21 \\
\hline
\end{tabular}

Setelah memaparkan hasil perhitungan mengenai jumlah kontingensi indeks gregory, langkah selanjutnya adalah melakukan perhitungan validitas pengembangan aplikasi "Kawan SMK" dengan rumus koefisiensi validitas isi indeks gregory berdasarkan tabel kontingensi dua ahli dengan hasil sebagai berikut:

Indeks Uji Ahli BK $\quad=0,89$

Indeks Uji Ahli Media $\quad=0,95$

Berdasarkan hasil perhitungan indeks gregory dua ahli tersebut, maka hasil penilaian prototipe 1 aplikasi "Kawan SMK" untuk meningkatkan perencanaan studi lanjut siswa SMK di Surakarta oleh ahli BK menunjukkan 0,89 (validitas tinggi) dan oleh ahli media menunjukkan 0, 95 (validitas tinggi). Sehingga pengembangan prototipe 1 pada aplikasi "Kawan SMK" layak digunakan sebagai media layanan bimbingan dan konseling dalam untuk meningkatkan perencanaan studi lanjut siswa SMK.

Selain memperoleh data kuantitatif, peneliti juga memperoleh data kualitatif yang berupa saran dari keempat validator yang digunakan sebagai dasar untuk memperbaiki produk aplikasi "Kawan SMK". Adapun saran dari validator yakni, (1) buku panduan bukan hanya difokuskan pada siswa namun juga informasi mengenai tahapan-tahapan yang dapat dilakukan oleh guru BK saat memberikan layanan kepada siswa menggunakan aplikasi "Kawan SMK"; (2) penjelasan mengenai keterkaitan materi yang dilampirkan dengan aplikasi "Kawan SMK"; (3) diberi penjelasan mengenai tahapan yang harus dilakukan oleh pengguna apabila mengalami kendala saat mendaftar atau masuk ke dalam aplikasi; (4) kata sandi yang digunakan dalam aplikasi tidak menggunakan tipe kata sandi yang kuat agar memudahkan guru BK saat mendaftar ke akun "Kawan SMK"; dan (5) menyeragamkan desain instrumen evaluasi dan lembar kerja dengan desain aplikasi. 
Setelah melakukan uji validitas ahli produk aplikasi "Kawan SMK", peneliti melakukan kegiatan revisi produk berdasarkan saran yang telah diberikan oleh validator, yakni revisi buku panduan, halaman depan aplikasi, dan desain instrumen evaluasi dan lembar kerja. Adapun produk aplikasi "Kawan SMK" yang telah dikembanglan hingga tahap main product revision dapat diunduh melalui https://bit.ly/KawanSMKapk.

\section{Pembahasan}

Perencanaan studi lanjut adalah proses yang dilakukan individu dalam menentukan langkah untuk mencapai pendidikan lanjutan sesuai dengan bakat dan minat yang dimiliki. Ginzberg juga mengemukakan pada usia 11-17 yang didalamnya termasuk usia siswa SMK, tahapan karier seorang individu adalah tentatif atau tahap pengenalan terhadap kemampuan, minat, dan jenis-jenis pekerjaan (Tarsidi, 2007: 4). Teori pemilihan karier, utamanya pemilihan studi lanjut John Holland memberikan kerangka tipologi yang mengaitkan antara kepribadian, lingkungan serta jenis kemungkinan karier yang akan diambil oleh seorang individu (Amalianita \& Putri, 2020: 3).

Hasil studi pendahuluan yang dilakukan oleh mahasiswa BK UNS angkatan 2012, sebanyak 50,58\% siswa SMK sangat membutuhkan peningkatan perencanaan studi lanjut dan 41,72\% siswa SMK membutuhkan peningkatan perencanaan studi lanjut. Hasil studi pendahuluan tersebut diperkuat dengan hasil wawancara kepada Drs. Daroji selaku guru BK SMK Negeri 1 Surakarta dan Dra. Darwati selaku guru BK SMK PGRI Surakarta yang mengungkapkan bahwa studi lanjut dianggap penting bagi siswa SMK karena hal tersebut dapat menunjang karier para siswa dimasa depan.

Perencanaan studi lanjut pada siswa dapat ditingkatkan dengan cara pemberian layanan perencanaan individual oleh guru BK. Salah satu strategi layanan perencanaan individual yang dapat dilakukan oleh guru BK dalam meningkatkan perencanaan studi lanjut bagi siswa SMK yakni mengembangkan media yang berisi informasi mengenai pendidikan lanjutan bagi siswa SMK. Sehingga, aplikasi "Kawan SMK" dikembangkan sebagai salah satu cara untuk mengurangi permasalahan mengenai perencanaan studi lanjut bagi siswa SMK.

Dalam pendidikan, penelitian dan pengembangan merupakan penelitian yang bertujuan untuk menghasilkan atau mengembangkan produk yang digunakan untuk pendidikan. Penelitian dan pengembangan adalah penelitian yang dilakukan secara bertahap sesuai dengan analisis kebutuhan dan penilaian produk. Menurut Borg dan Gall (1983: 775) penelitian dan pengembangan memiliki 10 langkah yang harus dilakukan oleh peneliti, langkah-langkah tersebut meliputi (1) research and information collecting; (2) planning; (3) develop preliminary form of product; (4) preliminary field testing; (5) main product revision; (6) main field testing; (7) operational product revision; (8) operational field testing; (9) final product revision; (10) desemination and implementation dan menghasilkan prototipe produk pengembangan aplikasi "Kawan SMK".

Aplikasi "Kawan SMK" merupakan produk media yang dikembangkan oleh peneliti untuk membantu guru BK dalam memberikan layanan perencanaan individual pada siswa SMK agar mereka dapat meningkatkan perencanaan studi lanjut melalui informasi-informasi yang terdapat pada materi yang tersedia. Pada penelitian dan pengembangan aplikasi "Kawan SMK" peneliti hanya sampai pada tahap main product revision sehingga hanya menghasilkan prototipe 1 dan prototipe 2 produk aplikasi "Kawan SMK". Penelitian dan pengembangan ini dilaksanakan hingga prototipe 2 karena penelitian bersifat multi tahun, yakni penelitian dan pengembangan yang dilakukan oleh perguruan tinggi dan berlangsung selama lebih dari satu tahun (Noor, 2010: 289). 
Prototipe 1 produk aplikasi "Kawan SMK" menghasilkan kumpulan materi, lembar kerja siswa, web, aplikasi, dan buku panduan bagi guru serta siswa. Sedangkan materi dalam produk aplikasi "Kawan SMK" meliputi pengetahuan diri, pengetahuan studi lanjut, informasi jurusan, informasi beasiswa, dan cerita dari alumni SMK yang melanjutkan pendidikan ke jenjang perguruan tinggi. Menu materi pengetahuan diri berisi mengenai macam-macam kecerdasan, minat, dan bakat yang dimiliki oleh individu. Menu materi pengetahuan studi lanjut berisi tentang jenis-jenis pendidikan tinggi, jenis-jenis perguruan tinggi, dan jalur masuk perguruan tinggi. Menu materi informasi jurusan berisi tentang informasi mengenai jurusan yang dapat diambil oleh siswa SMK sesuai dengan program keahliannya. Menu materi beasiswa berisi tentang informasi beasiswa yang dapat diambil oleh siswa SMK saat masuk ke perguruan tinggi baik sebelum mendaftar maupun saat sudah diterima menjadi mahasiswa. Materi tersebut disesuaikan dengan aspek-aspek perencanaan studi lanjut yakni pemahaman studi lanjut, informasi studi lanjut, perencanaan dan pengambilan keputusan studi lanjut (Yusuf, 2009), pengetahuan diri, sikap, dan keterampilan (Miskiya, 2013).

Prototipe 2 produk aplikasi "Kawan SMK" peneliti melakukan uji validitas ahli yang dilakukan kepada 2 ahli dibidang BK dan 2 ahli dibidang media. Uji validitas ahli bertujuan untuk menilai produk yang sedang dikembangkan (Plomp \& Nieveen, 2013: 38), uji validitas ahli terdiri atas validitas isi yang memuat indikator kualitas produk berdasarkan kesesuaian antara dasar teori dengan isi produk, dan validitas konstruk atau konsistensi antara komponen-komponen yang terdapat pada produk yang dikembangkan. Hasil dari uji validitas ahli dibidang BK yang dilakukan oleh 2 dosen BK menunjukkan bahwa produk memiliki validitas tinggi, yakni sebesar 0,89 , sehingga layak

digunakan sebagai media untuk meningkatkan perencanaan studi lanjut bagi siswa SMK dengan saran agar buku panduan khusus guru dilengkapi dengan langkah-langkah yang harus dilakukan oleh guru terhadap materi dan tindak lanjut setelah memberikan layanan. Sedangkan pada uji validitas ahli media yang dilakukan oleh dosen Pendidikan Teknik Kejuruan Teknik Mesin dan dosen Desain Komunikasi Visual juga menunjukkan bahwa produk memiliki validitas tinggi, yakni sebesar 0,95 , sehingga poduk layak digunakan dengan beberapa masukan yakni, (1) buku panduan bukan hanya difokuskan pada siswa namun juga informasi mengenai tahapan-tahapan yang dapat dilakukan oleh guru BK saat memberikan layanan kepada siswa menggunakan aplikasi "Kawan SMK"; (2) penjelasan mengenai keterkaitan materi yang dilampirkan dengan aplikasi "Kawan SMK"; (3) diberi penjelasan mengenai tahapan yang harus dilakukan oleh pengguna apabila mengalami kendala saat mendaftar atau masuk ke dalam aplikasi; (4) kata sandi yang digunakan dalam aplikasi tidak menggunakan tipe kata sandi yang kuat agar memudahkan guru BK saat mendaftar ke akun "Kawan SMK"; dan (5) menyeragamkan desain instrumen evaluasi dan lembar kerja dengan desain aplikasi.

Proses penelitian dan pengembangan produk aplikasi "Kawan SMK" peneliti juga mengalami hambatan, hambatan yang peneliti alami adalah menyesuaikan pengembangan "Kawan SMK" dengan kajian teori mengenai perencanaan studi lanjut agar produk yang dikembangkan dapat digunakan sesuai dengan tujuan pengembangan produk. Hambatan tersebut diatasi oleh peneliti dengan melakukan beberapa kali revisi dari masukan dosen maupun ahli yang menguji validitas produk.

Penelitian dan pengembangan produk aplikasi "Kawan SMK" juga terdapat kekurangan dan kelebihan. Adapun kekurangan pada pengembangan produk adalah (1) produk hanya dikembangkan hingga tahap main product revision yakni revisi produk setelah melakukan uji validitas ahli, dan (2) aplikasi yang dikembangkan masih sangat sederhana dan hanya dapat digunakan pada gawai dengan sistem operasi android. 
Sedangkan kelebihan pengembangan produk adalah (1) produk dapat digunakan sebagai media layanan bimbingan konseling secara efektif dan efisien; (2) produk tidak hanya dapat digunakan oleh siswa SMK kelas 12 namun juga siswa kelas 10 dan 11; (3) produk dapat membantu siswa SMK memperoleh pengetahuan tentang pendidikan lanjutan secara mudah; dan (4) produk memberi kemudahan guru BK dalam pemberian layanan kepada siswa tanpa harus bertatap muka. Peneliti juga berharap agar kelak pengembangan produk aplikasi "Kawan SMK" dilanjutkan hingga pada tahapan selanjutnya, yakni tahap main product revision, main field testing, operational product revision, operational field testing, final product revision, dan desemination and implementation. Sehingga produk dapat menjadi salah satu media yang digunakan oleh guru BK dalam memberikan layanan perencanaan individual kepada siswa yang berminat untuk melanjutkan pendidikan, dan turut menjadi portal pembelajaran daring seperti, Ruang Guru, Zenius, atau QuipperSchool.

\section{SIMPULAN}

Hasil studi pendahuluan berdasarkan hasil penelitian yang dilakukan oleh mahasiswa BK UNS angkatan 2012 di SMK se-Eks Karesidenan Surakarta menyatakan sebanyak 50,58\% siswa SMK sangat membutuhkan peningkatan perencanaan studi lanjut dan $41,72 \%$ siswa SMK membutuhkan peningkatan perencanaan studi lanjut. Hasil penelitian tersebut diperkuat dengan hasil wawancara yang dilakukan kepada Drs. Daroji selaku guru BK SMK Negeri 1 Surakarta dan Dra. Darwati selaku guru BK SMK PGRI Surakarta yang mengungkapkan mengenai pentingnya studi lanjut bagi siswa SMK untuk menunjang karier mereka di masa depan. Berdasarkan data tersebut maka diperlukan inovasi media bimbingan dan konseling untuk meningkatkan perencanaan studi lanjut bagi siswa SMK di Surakarta. Kajian teoretis mengenai pengembangan aplikasi "Kawan SMK" didapatkan dengan membaca literatur berkaitan dengan perencanaan studi lanjut dan aplikasi. Sehingga materi yang terdapat pada aplikasi "Kawan SMK" didasarkan pada aspek-aspek yang terdapat pada perencanaan studi lanjut. Hasil uji validasi produk yang dilakukan oleh dua ahli BK dan dua ahli media menyatakan bahwa produk aplikasi "Kawan SMK" dikatakan layak digunakan sebagai media Guru BK dalam pemberian layanan berkaitan dengan perencanaan studi lanjut siswa SMK.

\section{UCAPAN TERIMA KASIH}

Terima kasih penulis ucapkan untuk almamater Bimbingan dan Konseling Universitas Sebelas Maret

\section{DAFTAR PUSTAKA}

Alfurqon, H. S. (2012). Minat Siswa SMK Melanjutkan Studi Ke Perguruan Tinggi Pada Siswa Kelas XII Jurusan Teknik Kendaraan Ringan SMK Negeri 2 Surakarta Tahun Ajaran 2011/ 2012. Skripsi Dipublikasikan. Universitas Sebelas Maret.

Amalianita, B. \& Putri, Y. E. (2020). Perspektif Holland Theory serta Aplikasinya dalam Bimbingan dan Konseling Karier. Internasional Journal of Research in Counseling and Education. 1 (1), 1-7.

Asosiasi Penyelenggara Jasa Internet Indonesia. Laporan Survei Internet APJII 2019$2020(\mathrm{Q} 2)$

CNBC Indonesia. (2019). Penyumbang Pengangguran Tertinggi, Jumlah SMK Kok Ditambah? Diperoleh pada 12 Oktober 2019 dari https://www.cnbcindonesia.com/news/

Budiman, A. (2019). Kolom Pakar: Industri 4.0 vs Society 5.0. Humas Fakultas Teknik. Yogyakarta: UGM. 
Borg, W.R \& Gall, D. (1983). Educational Research : An Introduction. New York: Longman.

Damarjati, T. (2016). Mengubah Citra SMK Tak Lagi Sekolah Terakhir. Direktorat Pembinaan SMK. Diperoleh pada 21 September 2019 dari https://psmk.kemdikbud.go.id/konten/2500/mengubah-citra-smk-tak-lagi-sebagaisekolah-terakhir

Depdiknas. (2008). Peraturan Pemerintah Republik Indonesia No. 19 Tahun 2005 tentang Standar Nasional Pendidikan. Jakarta.

Gysbers, C. N \& Henderson, P. (1976). Developong and Managing: Your School Guidance \& Counseling Program. America School Counseling Association: Alexandria.

Indriyanti, N. Siswandari, Ivada, E. (2013). Faktor-faktor yang Memengaruhi Minat Melanjutkan Pendidikan ke Perguruan Tinggi Pada Siswa Kelas XII Akuntansi SMK Negeri 6 Surakarta Tahun 2013. Jurnal Pendidikan Universitas Sebelas Maret. 1(2), 1-10. Diperoleh pada 25 September 2019, dari https://jurnal.fkip.uns.ac.id/index.php/ekonomi/article/view/2382

Irawan, T. (2018). Pengembangan Permainan Simulasi Dakon untuk Meningkatkan Keterampilan Merencanakan Karier Bagi Peserta Didik Sekolah Menengah Atas (SMA). Skripsi. Surakarta.

Kompas. (2019, 13 Agustus). Mendorong Lahirnya Wirausaha Muda Lewat Kompetisi Perusahaan Siswa. Diperoleh pada 13 Oktober 2019 dari https://edukasi.kompas.com/read/2019/08/13/20524161/

Lukitaningrum, H. (2016). Pengembangan Media Pembelajaran Berbasis Web pada Materi Basis Data di Sekolah Menengah Kejuruan Kelas XI. Yogyakarta: Universitas Negeri Yogyakarta.

Lulusan SMK: Bekerja, Wirausha, atau Kuliah? (2019). Jombang: Universitas KH. Abdul Wahab Hasbullah

Miskiya, L. (2013). Faktor Determinan Kemampuan Perencanaan Karier Siswa Kelas XI SMA Negeri Se-Kabupaten Tegal Tahun Ajaran 2013/ 2014. Skripsi dipublikasikan Universitas Negeri Semarang.

Noor, I H M. (2010). Penelitian dan Pengabdian Masyarakat pada Perguruan Tinggi. Jurnal Pendidikan dan Kebudayaan. 16 (3), 285-297.

Onday, O. (2019). Japans Society 5.0: Going Beyond Industry 4.0. 1PhD student, Yeditepe University Department of Business Administration. Diperoleh pada 30 September 2019, dari https://www.researchgate.net/publication/330500307_Japan's_Society_50_ Going_Beyond_Industry_40

Peraturan Menteri Pendidikan dan Kebudayaan No. 70 Tahun 2013. Kerangka Dasar \& Struktur Kurikulum SMK/ MAK. 2013. Jakarta.

Plomp, T. \& Nieveen, N. (2013). Educational Design Reseacrh. Enschede: Netherlands Institute for Curriculum Development.

Riyadi, A. S., Retnadi, E., \& Supriatna, A. D. (2013). Perancangan Sistem Informasi Berbasis Website Subsistem Guru Di Sekolah Pesantren Persatuan Islam 99 Rancabango. Jurnal Algoritma, 9 (2), 327-337.

Setiaji, K. \& Rachmawati, D. (2017). Minat Melanjutkan Studi Perguruan Tinggi Siswa SMKN Kota Semarang. Jurnal Pendidikan Ekonomi.10(1), 45-59. Diperoleh pada 11 Juni 2019, dari http://journal2.um.ac.id/index.php/jpe/article/view/1598

Setiawan, Y. (2017). Mengubah Citra SMK Tak Lagi Sebagai Sekolah Terakhir 
Sumual, H. \& Sumual, H. M. (2016). Production Unit of Vocational High School: Learning Resource and Enterpreneurships Place. Innovation of Vocational Technology Education, 12(2), 60-65. Diperoleh pada 25 Mei 2019, dari https://media.neliti.com/media/publications/66577-EN-production-unitofvocational-high-schoo.pdf

Tarsidi, D. (2007). Teori perkembangan karir. Jurnal Universitas Pendidikan Indonesia.

Usman, H. \& Darmono. (2016). Pendidikan Kejuruan Masa Depan. Yogyakarta: Pusat Kurikulum dan Perbukuan Badan Penelitian dan Pengembangan Kementerian Pendidikan dan Kebudayaan.

Yusuf, Syamsu. (2009). Program Bimbingan dan Konseling Di Sekolah. Bandung: Rizki Press.

\section{PROFIL SINGKAT}

Elwas Berdha Krismona adalah mahasiswa Program Studi Bimbingan dan Konseling, Fakultas Keguruan dan Ilmu Pendidikan, Universitas Sebelas Maret.

Dr. Ribut Purwaningrum, M. Pd adalah Dosen Program Studi Bimbingan dan Konseling, Fakultas Keguruan dan Ilmu Pendidikan, Universitas Sebelas Maret. Ia juga merupakan pcychological wellbeing reseacher.

Dr. Naharus Surur, M. Pd adalah Dosen Program Studi Bimbingan dan Konseling, Fakultas Keguruan dan Ilmu Pendidikan, Universitas Sebelas Maret. 